\title{
Profile: Moving Stonehenge
}

Barnabas Harris

University College London, $U K$

\section{Introduction}

Over the course of the twentieth century a number of experimental studies have investigated the construction of megalithic monuments such as Stonehenge (Atkinson, 1956; Osenton, 2001; Parry, 2000; Pavel, 1992; Washington, 2010; Whitby \& Richards, 1997). These studies have typically highlighted the challenges posed - or benefits offered - by one method of manipulating a heavy load in relation to another. In certain cases (e.g. Atkinson 1956), archaeologists have used data from such experiments to estimate the probable length of time that the construction of Stonehenge, or similar monuments, would have taken. These experiments have occasionally generated significant interest from national and international media outlets, a fact that illustrates their potential to act as powerful devices for academic outreach and or public archaeology initiatives today. The experiment discussed below, Moving Stonehenge, conducted on May $23^{\text {rd }} 2016$ as part of UCL's Festival of Culture succeeded in capturing the public's imagination and was reported extensively by the UK national press (BBC News 2016; Beal \& O'Hare 2016; Knapton 2016), the international Associated Press, and a number of popular science and technology websites (Condliffe 2016; Metcalfe 2016). In addition to documenting the planning and execution of the experiment, this report also explores aspects of its public engagement.

\section{Project background}

The experiment formed part of the author's AHRC-funded doctoral project, based at the UCL Institute of Archaeology in London. This author's project, 'Landscapes of Labour', aimed to re-evaluate ideas around Neolithic and Early Bronze Age social organisation by examining how the amount of time invested in building monumental architecture changed in Wessex from c. 4000-2000BC. As monuments such as Stonehenge attest, the quarrying, transportation and manipulation of individual large stones (megaliths) often formed an important part of the overall building sequence of prehistoric monuments in Britain. But exactly how labour intensive was the transportation of megaliths in prehistory? The Moving Stonehenge experiment was designed to investigate just this by measuring - amongst other variables - the numbers of individuals that were required to transport a concrete block using a wooden sledge, timber slipeay and ropes, a technique similar to that used by $20^{\text {th }}$-century megalith-building groups in Asia (Hutton, 1922). The experiment was not 'to scale', as the concrete block used weighed approximately half as much as one of the smallest intact sarsen stones (station stone 93) at Stonehenge (Parker Pearson, et al., 2012: 59). Regardless, there is no reason that the experimental findings could not be applied to discussions relating to the transport of heavier loads of up to around 2 tonnes. This is the average weight of Stonehenge's bluestones, which were transported from west Wales to Wiltshire sometime during the late $4^{\text {th }}$ millennium BC (Darvill, 2007; Parker Pearson, 2012).

The experiment also provided an opportunity to engage with the public's pre-existing perceptions of prehistoric monument construction. As Colin Richards (2013: 5) has noted, there is a widespread assumption that prehistoric monument building (including the movement of large stones) was an economically-wasteful, largely technical process. In recent discussions around how structures like Stonehenge were built this belief has undoubtedly 'rationalised' explanations that required the least number of people. Yet this is at odds with ethnographic studies of contemporary megalith-building societies (Adams \& Kusumawati, 
2010; Heizer, 1966; Hoskins, 1986; Hutton, 1929), within which organisers of stone moving events frequently involved as many people as physically possible as part of a competitive display of wealth (Richards 2013: 5). In these societies, the ability to amass large groups of individuals was directly related to one's own standing within the community. The present experiment aimed to offer the public an opportunity to participate in the movement of a large replica stone, using deliberately 'inefficient' means (i.e. as a large group) and demonstrated an alternative, more socially-centred, reading of prehistoric monument construction.

Financial support for the experiment was provided by the UCL Festival of Culture 2016 - a five-day college-wide event featuring talks and activities from staff and students across many of UCL's departments.

\section{Planning the activity}

It was essential to host the experiment in Gordon Square Park, Bloomsbury for a number of reasons. Firstly, the Institute of Archaeology is situated opposite Gordon Square Park and hosting the activity here would therefore forge a symbolic link between the experiment and the wider activities of UCL and the Institute of Archaeology. More prosaically, the close proximity of the building to Gordon Square Park greatly simplified the process of transferring equipment and volunteers from the building to the experimental site. The central London location offered another, somewhat less tangible, benefit; impact through juxtaposition. As is perhaps obvious, a small crowd of people hauling an enormous concrete block lashed to a $3 \mathrm{~m}$ long wooden sledge is not particularly in keeping with the somewhat urbane surroundings of London's Bloomsbury district, situated just 3 minutes walk from Euston Train Station. Doubtless, the faintly absurd contrast between these two worlds was not lost on a number of journalists and broadcasters, as became clear during press interviews before and after the event.

In real terms, the central London location meant that the activity directly engaged a demographic that may not usually come into contact with large scale experimental archaeology, an activity that is frequently restricted to privately owned land in rural locales. In 2015, the Office for National Statistics reported that over $69 \%$ of the individuals residing in Bloomsbury were either professionals, managers, directors and senior officials or associate professional and technical staff (ONS 2015). In addition to this, UCL, SOAS and The University of London have campuses in and around Bloomsbury, making the area popular with students. Finally, the area is also frequented by international tourists and other visitors to the city, many of who were likely to have seen promotional material relating to the wider UCL Festival of Culture.

Permission to use Gordon Square park fell squarely on its owners, the University of London. After a number of email exchanges with a supportive if not concerned head of facilities, it became clear that it would not be possible to run the activity without a cast iron promise to protect the park's immaculately maintained grass. Effectively, this meant that the sledge could only be hauled over wooden tracking and that the experiment would have to be abandoned entirely if the ground was considered too waterlogged on the day. Ultimately, the advantages that using the space conferred - both in terms of practicality and from a public engagement perspective - outweighed these restrictions and risks.

Though valuable, direct public and student involvement raised a number of safety concerns. The most severe risks centred around the concrete block and sledge rig injuring someone, either by sledge failure resulting in the block falling, or by someone accidentally being struck by the sledge or block in transit. Working closely with the departmental and college safety officers, it was decided that these concerns could be allayed by limiting the involvement of volunteers to either hauling on the ropes (which would ensure they stayed c. 
$10 \mathrm{~m}$ away from the sledge at all times) or moving the trackway once the sledge was stationary and had been deemed secure. Trusted members of the experimental team undertook more hazardous jobs, such as levering up the sledge to adjust the wooden tracking beneath.

In terms of logistics, the assistance of one of UCL's main construction contractors, Wilson James, was invaluable. After being reassured over some initial concerns around safety, the logistics zone team (based directly in front of the Institute of Archaeology) were more than happy to loan out a makeshift 'Stonehenge stone' (in fact, a heavy-duty, bright red road barrier) and even offered to transport it to and from the experimental site using a fork lift truck. A host of other traders and organisations also contributed essential time and resources to the project. Of all such contributions, the sledge itself stood apart as the most critical. The $3.5 \mathrm{~m}$ long, $\mathrm{v}$-shaped section of mature sycamore was procured by an arborist and woodland management unit both based in Shropshire, UK. Once the appropriate section had been felled and lowered safely by rope, a modern, petrol-powered chainsaw was used to shape it into a 'shura' sledge. The form of the sledge was based on diagrams of Neolithic examples recovered from Japan (Shimotsuma et al. 2011). Felling and or shaping the sledge using stone tools was recognised as a potential opportunity for further experimental work but regrettably time constraints prevented this from being undertaken.

The experiment was primarily publicised by the UCL Festival of Culture press attaché, who worked tirelessly to convince local and national media outlets to report on the project. Her efforts were rewarded when The Evening Standard dispatched a photographer to come and photograph the sledge and block in preparation for a small piece on the event. The disappointment was palpable, however, when the photographer was led to the bright red concrete road barrier destined to be used on the day. 'It doesn't look like Stonehenge', summed up the stark difference between news stories that presumably get the requisite number of views (or clicks) and those that don't. Whether the block was red or a more convincingly 'stone-like' grey was largely irrelevant from an experimental perspective but, as the press attaché took greats pains to explain, would be critical in terms of generating widespread media attention. Indeed, the photographer informed us that the lacklustre, red block may jeopardise the chances of the story running at all. In the event, the story ran but with a generic image of Stonehenge (Razaq 2016). The publicist for the event, Zena Howard remarked:

'the visual aspects of this project were paramount: journalists' want a good picture and for TV coverage there must be a visual story.' (Z. Howard, pers. comm., 02 July 2016)

In light of the above, the block was duly repainted as the experiment aimed to engage as wider audience as possible and in this case the desired change was quick and inexpensive to make. Furthermore, repainting the block would not in any material way inadvertently influence the experimental variables being recorded

\section{Moving Stonehenge}

In stark contrast to the torrential rain of the preceding days, the morning of Monday $23^{\text {rd }}$ May was fine and dry in central London. Thankfully a quick examination of the grass on Gordon Square Park showed it to be firm enough to proceed with the experiment. 45 students, UCL staff and members of the public attended the morning safety and induction talk, which also featured an engaging session on the ethnography of megalithic construction by Professor Mike Parker Pearson. Participants were briefed on the experimental procedure and a number 
of key safety issues were also highlighted. All participants were asked to sign a document showing that they had attended the induction. At 12:30pm the participants were led into Gordon Square Park where a public cordon was already in place. The concrete block lay already lashed to the sledge, perched atop several pieces of tracking. Several film crews and photographers were already present and were busy jostling for the best position from which to film the inaugural haul. 14 participants were given the task of removing the lengths of slipway from behind the advancing sledge and replacing them in front of it before the next haul. A further 10 individuals were then asked to take up positions on the two lengths of rope attached to the sledge.

Unexpectedly, the force generated by just 10 individuals was sufficient to move the load. This was at odds with the author's calculations which suggested that around 15 people would be required. In fact, the synchronised effort of 10 haulers appeared to be easily enough to send the sledge rumbling loudly across the tracking, much to the delight of the participants and spectators. Over the next two hours, a further 22 trials were conducted with varying numbers of individuals, either pulling on the ropes or adjusting the slipway. These subsequent experiments demonstrated that the minimum number of individuals required to move the load was indeed 10. The maximum speed attained throughout the experiment was 1 metre per second. Additionally, it was noted that, when cornering, speeds were significantly decreased and careful placement of the slipway was required to prevent the sledge from tipping. An added benefit of the slipway was that the sledge could be rotated horizontally in situ, which made navigation of the experimental area significantly easier than if it had required a large turning circle. In total, the experiment ran from $1 \mathrm{pm}$ until $3 \mathrm{pm}$, with a 20 minute break taken roughly halfway through.

The media frenzy grew exponentially as the day wore on. Film crews from ITN, BBC and the Associated Press queued patiently for an interview regarding the significance of the experiment's findings. Understandably, many journalists focused on establishing how the experiment had changed our understanding of Stonehenge. Interestingly, the author's surprise at how few individuals were required to move the load became the de facto angle of the majority of the news coverage. Article titles such as, 'Stonehenge wasn't so hard to build after all, archaeologists discover' (Knapton, 2016) summarised the tone of the resulting coverage. Though this was by no means a negative development, it is worth considering how a seemingly benign observation regarding the accuracy of a calculation can define how a piece of public archaeology is represented. Doubtless, the preferred angle of coverage was also influenced more generally by a preference for science-based news stories to adopt a 'myth-busting' type narrative. In this case, the experimental results were used to explode the commonly-held idea that the construction of Stonehenge probably involved large numbers of people.

\section{Conclusion}

Hard data generated by the experiment will to be incorporated within the author's $\mathrm{PhD}$ thesis and will assist in quantifying the minimum time invested in transporting megaliths in prehistory. More broadly, the experiment demonstrated the viability of megalith transport using a v-shaped 'shura' sledge without pulling it over cylindrical wooden rollers. The belief that wooden rollers were used to transport megaliths in prehistory is, in fact, a common misconception (Davison, 1961; Harris, 2015). Additionally, a number of observations can be made from a public engagement perspective. Firstly, whilst it presented additional challenges from a logistical and safety point of view, free public involvement helped publicise the event, 
as these comments from the UCL press attaché for the project, Zena Howard (pers. comm., 02 July 2016), confirm;

The general public element to the experiment gave me a 'call to action' which would appeal to journalists because a) their article can ask people to get involved and this also helps pre-publicity and b) crews could film the general public taking part, not just show archaeologists.

Aside from being directly involved, the ways that the general public engaged with the activity varied. Around 100 simply gathered to watch, spending some 30 minutes or so viewing the spectacle whilst eating their lunches. Others took a more direct interest, calling out tips on the best ways to carry out the task and enquiring about the archaeological evidence for the various materials that were employed in the experiment. Furthermore, questions were indeed raised, both during and after the experiment, about the technical efficiency of the chosen technique and whether this would make it more or less likely to have been used in prehistory. From informal discussions with participants, it became clear that directly participating in an archaeological experiment was an entirely novel experience for many of them. A US-based tourist, who had visited Stonehenge earlier in their holiday, remarked that it was now 'unbelievable' to be involved in an experiment that was contributing to our understanding of the iconic monument. In this sense, projects of this nature offer both UK citizens and tourists the opportunity go beyond simply visiting national heritage assets. Instead, they forge a space for these groups to actively take part in shaping our shared understanding of them.

\section{Acknowledgements}

The author would firstly like to thank Rob Smith of R. Smith Forestry and Watch Oak for their great efforts in sourcing and shaping the experimental sledge. Warm thanks is also extended to Rich Edwards and all the team at Englefield Estate for their kind donation of timber (and indeed time). Thanks also to Wilson James Ltd. For their logistical support and the University of London for trusting the author with access to Gordon Square Park. The author is also indebted to the UCL Institute of Archaeology departmental safety officer, Sandra Bond, for her patience and professionalism. The author would also like to thank undergraduate students Adam Rigby, Arthur Starzec and Daniel Hobbins for their assistance on the day. Finally, thank you to Professor Mike Parker Pearson, Catherine Thompson and all the other volunteers involved on the day.

\section{Bibliography}

Adams, R.L. \& A. KusumawatI. 2010. 2 The Social Life of Tombs in West Sumba, Indonesia Archeological Papers of the American Anthropological Association 20: 17-32.

ATKINSON, R.J.C. 1956. Stonehenge. London: H. Hamilton.

BBC NEWs. 2016. How hard was it to build Stonehenge? BBC News. Accessed June 23. http://www.bbc.co.uk/news/uk-36364498.

BeAL, A. \& R. O'HARE. 2016. How many people did it take to build Stone Henge? Mail Online, May 23. http://www.dailymail.co.uk/sciencetech/article-3605225/How-people-didbuild-Stonehenge-Volunteers-drag-ONE-TONNE-concrete-slab-recreate-stone-ageeffort.html. 
Condliffe, J. 2016. This Might Be How Workers Moved the Stones of Stonehenge Gizmodo. http://www.gizmodo.in/science/This-Might-Be-How-Workers-Moved-the-Stones-ofStonehenge/articleshow/52414827.cms.

DARVILL, T.C. 2007. Stonehenge: The Biography of a Landscape. Tempus.

DAVISON, C.S.C. 1961. Transporting Sixty-Ton Statues in Early Assyria and Egypt Technology and Culture 2: 11.

HARRIS, B. 2015. Roll Me a Great Stone: The Roller Hypothesis and other legends, in .

HEIZER, R.F. 1966. Ancient Heavy Transport, Methods and Achievements Science 153. New Series: 821-30.

HoskINS, J.A. 1986. So My Name Shall Live: Stone-Dragging and Grave-Building in Kodi, West Sumba Bijdragen tot de Taal-, Land-en Volkenkunde, 31-51.

HutTON, J.H. 1922. The Meaning and Method of the Erection of Monoliths by the Naga Tribes. The Journal of the Royal Anthropological Institute of Great Britain and Ireland 52: 242-49.

- 1929. Assam Megaliths Antiquity 3: 324-338.

KNAPTON, S. 2016. Stonehenge wasn't so hard to build after all, archaeologists discover The Telegraph. http://www.telegraph.co.uk/science/2016/05/23/stonehenge-wasnt-sohard-to-build-after-all-archaeologists-disco/.

MetcalfE, T. 2016. Heave-Ho! Stonehenge Experiment May Show How Monument Was Built Live Science. http://www.livescience.com/55106-stonehenge-experiment-howmassive-stones-were-moved.html.

ONS. 2015. Labour Market Profile - Camden. https://www.nomisweb.co.uk/reports/Imp/la/1946157246/report.aspx?town=bloo msbury\#schedule.

OSENTON, C. 2001. Megalithic Engineering Techniques: Experiments Using Axe-Based Technology Antiquity 75: 293-98.

PARKER PeARSON, M. 2012. Stonehenge: Exploring the greatest Stone Age mystery. Simon and Schuster.

Parker Pearson, M., M. Abbott., H. Anderson-Whymark., D. Aspden., A. Badcock., T. Davies., M. FELTER., R. IXER. \& C. RICHARDS. 2012. Stonehenge Laser Scan: Archaeological Analysis Report. Report 32/2012. UK: English Heritage. http://services.englishheritage.org.uk/ResearchReportsPdfs/032_2012WEB.pdf.

PARRY, R.H.G. 2000. Megalith mechanics Proceedings of the ICE - Civil Engineering 138: 18392.

PAVEL, P. 1992. Raising the Stonehenge lintels in Czechoslovakia Antiquity 66: 389-438.

RAZAQ, R. 2016. Take part in Stonehenge experiment: How many people does it take to lift one block? | London Evening Standard The Evening Standard, May 19. http://www.standard.co.uk/goingout/attractions/take-part-in-stonehengeexperiment-how-many-people-does-it-take-to-lift-one-block-a3251801.html.

RICHARDS, C. 2013. Building the Great Stone Circles of the North. Windgather Press.

Shimotsuma, Y., M. OgatA., T. NAKATSUJI. \& Y. OzaWA. 2011. History of Tribology in Ancient Northeast Asia - The Japanese Sledge and the Chinese Chariot - Tribology Online 6: 174-79.

WASHINGTON, N.G.S.P.O.B. 98199. 2010. Stonehenge Built With Balls? http://news.nationalgeographic.com/news/2010/12/101210-stonehenge-balls-ballbearings-science-rolled/. 
WhitBY, M. \& J. RICHARDS. 1997. The Engineering of Stonehenge, in C. Renfrew \& B. Cunliffe (ed.) Science and Stonehenge. Oxford [etc.]: Oxford University Press. 